\title{
Onderzoeksnotitie: Vergrijzing en arbeidsveiligheid ${ }^{1}$
}

\author{
Anita Venema en Ernest M.M. de Vroome*
}

Het doel van dit artikel is na te gaan wat de mogelijke effecten zijn van de vergrijzende arbeidsmarkt op de arbeidsveiligheid in Nederland en op basis daarvan conclusies te trekken over effectief leeftijdsbewust personeelsbeleid. In dit artikel worden gegevens over arbeidsongevallen in Nederland, demografische en persoonsvariabelen en werkkenmerken uit de Nationale Enquête Arbeidsomstandigheden (NEA) 2005 met behulp van regressieanalyse multivariaat geanalyseerd. De resultaten laten zien dat het totale ongevallenpercentage en het percentage arbeidsongevallen met verzuim daalt naarmate men ouder wordt, terwijl het percentage arbeidsongevallen met verzuim langer dan één maand iets stijgt met de leeftijd. Uit de gevonden interactie-effecten blijkt dat er subgroepen zijn waarvoor het effect van leeftijd op het ongevalrisico anders uitvalt. De leeftijdsgebonden daling van de kans op een arbeidsongeval is niet van toepassing op alle werknemers, noch op alle sectoren. Aangezien jongeren het hoogste risico lopen op een arbeidsonge$\mathrm{val}$, zal een toename van het aantal oudere werknemers op de arbeidsmarkt een gunstig effect hebben op het totale aantal arbeidsongevallen in Nederland.

Trefwoorden: vergrijzing, arbeidsveiligheid, arbeidsongevallen, ongevalsrisico

\section{Inleiding}

De arbeidsparticipatie van ouderen is de laatste jaren in Nederland fors toegenomen (CPB, 2005; de Boer, 2006; Smulders, 2006). Dit komt deels door de vergrijzing en deels doordat meer ouderen een baan hebben. In 2005 was bijna een kwart van de werkzame beroepsbevolking 50 jaar of ouder (CBS, 2006). Eén aspect van vergrijzing is tot nu toe echter maar weinig belicht: het effect van vergrijzing op de arbeidsveiligheid. Het aandeel oudere werknemers stijgt. Wat heeft dit voor gevolgen voor de arbeidsveiligheid in Nederland? Leeftijdsbewust personeelsbeleid wordt steeds belangrijker (SER, 2006). Geldt dit ook op het specifieke vlak van het veiligheidsbeleid?

Smulders (2005) constateert op basis van gegevens uit de Nationale Enquête Arbeidsomstandigheden 2003 dat er ten aanzien van arbeidsongevallen met en zonder verzuim van werknemers geen duidelijke leeftijdseffecten zijn vast te stellen. Hooguit is een lichte verhoging van het aantal ongevallen te zien bij de jongste leeftijdsgroepen, vooral bij mannen. In de Monitor Arbeidsongevallen 2004 (Venema \& Bloemhoff, 2006) komt voor arbeidsongevallen die leiden tot verzuim eveneens naar voren dat de kans op een ongeval het hoogst is voor jongere werknemers. Bij ongevallen met ziekenhuisopname en dodelijke arbeidsongevallen valt echter ook het hoge risico van oudere werknemers op. Het lijkt erop dat als ouderen een ongeval overkomt, de gevolgen relatief ernstig zijn.

Meestal wordt aangenomen dat er inderdaad een negatieve relatie is tussen leeftijd en arbeidsongevallen: de kans op een arbeidsongeval neemt af met het ouder worden (Frone \& Barling, 2004). Jongeren zouden gevaarlijker en minder afwisselend werk doen, minder verantwoordelijkheid hebben voor hun werk, meer impulsief zijn, zich meer afzetten, sen-

\footnotetext{
* Anita Venema en Ernst de Vroome zijn verbonden aan TNO Kwaliteit van Leven. Correspondentieadres: drs. A. Venema, TNO Kwaliteit van Leven, Polarisavenue 151, Postbus 718, 2130 AS Hoofddorp. E-mail: Anita.Venema@tno.nl.
} 
satie zoeken, en zich meer onkwetsbaar voelen (Frone, 1998; Loughlin \& Frone, 2004). Een belangrijk verschil is echter dat ouderen na een ongeval ernstiger letsel (fracturen en multipel letsel) oplopen en langer moeten herstellen (Rogers \& Wiatrowski, 2005). Pransky et al. (2005) vinden echter dat als ouderen weer aan het werk gaan na een arbeidsongeval, ze het niet slechter of zelfs beter doen dan jongeren.

Doel van dit artikel is na te gaan wat de mogelijke effecten zijn van de vergrijzende arbeidsmarkt op de arbeidsveiligheid in Nederland. Hierbij is gebruikgemaakt van data uit de Nationale Enquête Arbeidsomstandigheden 2005 over arbeidsongevallen (Van den Bossche et al., 2006). De hoofdonderzoeksvraag luidt: Wat is de samenhang tussen leeftijd en het ongevallenpercentage?

Daarnaast wordt onderzocht of en in welke mate leeftijd samenhangt met verzuim na een ongeval. De verwachting hierbij is dat ouderen een hoger risico hebben op ongevallen met langdurig verzuim, omdat ouderen in het geval van een ongeval een hoger risico lopen op letsel en daarvan langer moeten herstellen. Ten slotte wordt onderzocht in welke subgroepen de relatie tussen leeftijd en ongeval met name sterk positief of sterk negatief is, om daaruit conclusies te kunnen trekken over effectief leeftijdsbewust personeelsbeleid.

\section{Methode}

Dit artikel betreft de secundaire analyse van gegevens over arbeidsongevallen uit de Nationale Enquête Arbeidsomstandigheden (NEA) 2005. Eind 2005 zijn 80.000 werknemers benaderd met de mogelijkheid om een papieren vragenlijst of een internetenquête in te vullen. Het gaat om personen van 15 tot en met 64 jaar die betaald werk verrichten in loondienst. Het steekproefkader is afgeleid uit het zogenaamde banenbestand van het CBS. Het responspercentage bedroeg 32,5 (23.408 werknemers). Voor de gevonden responsverschillen is gecorrigeerd door middel van weging (van den Bossche et al., 2006).
In de enquête zijn vier vragen over arbeidsongevallen opgenomen. De eerste vraag heeft betrekking op het aantal ongevallen dat een werknemer in het afgelopen jaar is overkomen. De overige vragen spitsen zich toe op het meest recente ongeval en gaan na welk soort letsel is opgelopen, of er sprake was van verzuim als gevolg van het ongeval en wat de duur van dit verzuim was. Op basis van deze variabelen zijn drie afhankelijke variabelen opgesteld: (1) al dan niet een ongeval hebben gehad in de laatste twaalf maanden, (2) al dan niet een ongeval hebben gehad dat tot verzuim aanleiding gaf, en (3) al dan niet een ongeval hebben gehad dat tot verzuim langer dan een maand aanleiding gaf. Deze drie afhankelijke variabelen zijn elk afzonderlijk multivariaat met regressieanalyse geanalyseerd op een verzameling van demografische en persoonsvariabelen, en een aantal mogelijk verklarende werkkenmerken (zie tabel 1).

Aangezien de laatste onderzoeksvraag betrekking heeft op de vraag in welke subgroep of subgroepen de relatie tussen leeftijd en ongeval met name sterk positief of sterk negatief is, zijn alle interactietermen tussen leeftijd en elke andere determinant berekend en in de regressievergelijking opgenomen. Omdat onze interesse uitgaat naar het Relatieve Risico $(R R)$ van een risicofactor, gebruiken we het Cox proportional hazards regressieanalysemodel, waarbij de tijd als een constante wordt opgenomen (Skov et al., 1998; Thompson et al., 1998).

Om de resultaten en vooral de interacties goed te kunnen interpreteren, zijn vervolgens de multivariaat gecorrigeerde Relatieve Risico's teruggerekend naar 'absolute' kansen. Dat is gedaan door voor een groot aantal subgroepen (combinaties van leeftijd en bijvoorbeeld bedrijfstak) het regressiemodel 'in te vullen', en te berekenen wat de multivariaat gecorrigeerde kans op een ongeval is in de betrokken subgroep. Omdat relatief weinig ouderen en jongeren werken, is bij de keuze voor de 'in te vullen' punten van de verschillende regressielijnen gekozen voor de volgende strategie. De regressielijnen worden weergegeven voor het interval 'gemiddelde \pm één standaarddeviatie'; hierin valt 'normaliter' circa twee derde (68,3\%) van de betrokke- 
nen. De gehele subgroep is echter betrokken bij de berekening van de parameters van die groep.

\section{Resultaten}

In figuur 1 staan de ongevallenpercentages behorend bij elke afhankelijke variabele weergegeven naar leeftijd. Het hoogste ongevallenpercentage wordt duidelijk gevonden bij jongere werknemers. Het totale ongevallenpercentage daalt met $1,1 \%$ per leeftijdsjaar $(R R=$ $0,989, p<0,001)$, en het percentage arbeidsongevallen met verzuim daalt met $0,8 \%$ per leeftijdsjaar $(R R=0,992, p<0,02)$. Het percentage arbeidsongevallen met verzuim langer dan een maand stijgt echter met 2,2\% per leeftijdsjaar $(R R=1,022, p<0,001)$. Deze trends zijn relatief klein, maar gezien het grote aantal respondenten in de NEA 2005 wel significant.

In figuur 2 wordt de relatie tussen verzuimduur na een arbeidsongeval en leeftijd weergegeven. Duidelijk wordt dat de 'onderste' categorieën (geen verzuim en korte verzuimepisodes) in grootte afnemen met de leeftijd, en de langere verzuimepisodes toenemen met de leeftijd. Zo komt de categorie 'verzuim langer dan 6 maanden' niet of nauwelijks voor onder de 30 jaar, en neemt daarna snel in omvang toe. De Spearman correlatie tussen beide ordi- nale variabelen is dan ook positief en significant $(r=+0,10, p<0,001)$ : naarmate men ouder is, neemt de verzuimduur na een bedrijfsongeval toe.

In tabel 1 zijn de resultaten van de multipele regressieanalyse opgenomen. Uit deze tabel kan worden opgemaakt dat de bivariate relatie tussen leeftijd en ongeval en ongeval met verzuim volledig wordt verklaard door de in het model opgenomen overige variabelen. De kans op een arbeidsongeval is 19 procent kleiner onder degenen die een relatief hoge mate van autonomie ervaren in vergelijking met degenen die relatief weinig autonomie ervaren $(R R=0,81)$. De kans op een arbeidsonge$\mathrm{val}$ is eveneens kleiner als men relatief langdurig beeldschermwerk doet $(R R=0,78, p<$ 0,001), maar groter als de werkdruk relatief hoog is $(R R=1,17)$, als er sprake is van emotioneel zwaar werk $(R R=1,26)$, als er sprake is van relatief veel fysieke belasting op het werk $(R R=2,16)$, als er sprake is van veel geluidslast op het werk $(R R=1,27)$, als er sprake is van relatief veel agressie op het werk $(R R=$ $1,89)$, als er sprake is van gevaarlijk werk $(R R$ $=2,31$, en als er vaak wordt gewerkt met gevaarlijke stoffen $(R R=1,19)$. Ten slotte hebben werknemers met een arbeidshandicap een grotere kans op een arbeidsongeval $(R R=1,29)$ in vergelijking tot werknemers die geen arbeidshandicap hebben. Vooral fysieke belasting, gevaarlijk werk en agressie op het

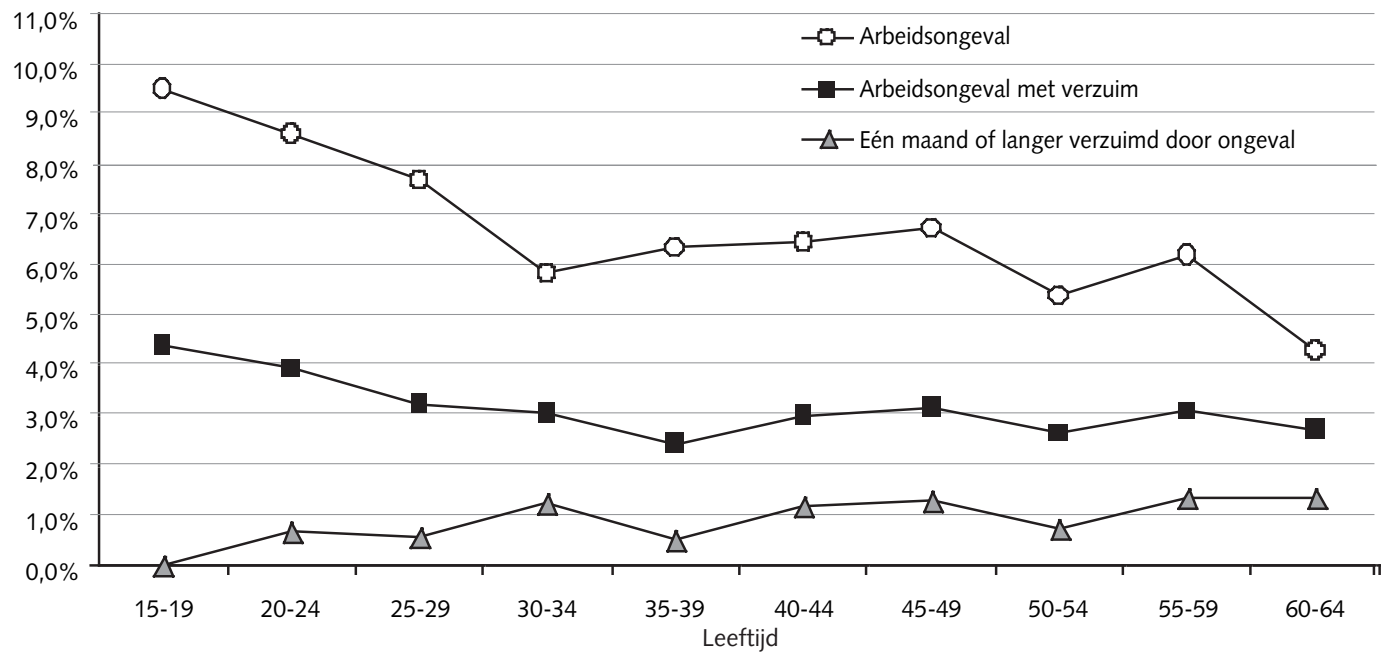

Figuur 1 Arbeidsongevallen naar leeftijd $(N=20.986)$ 


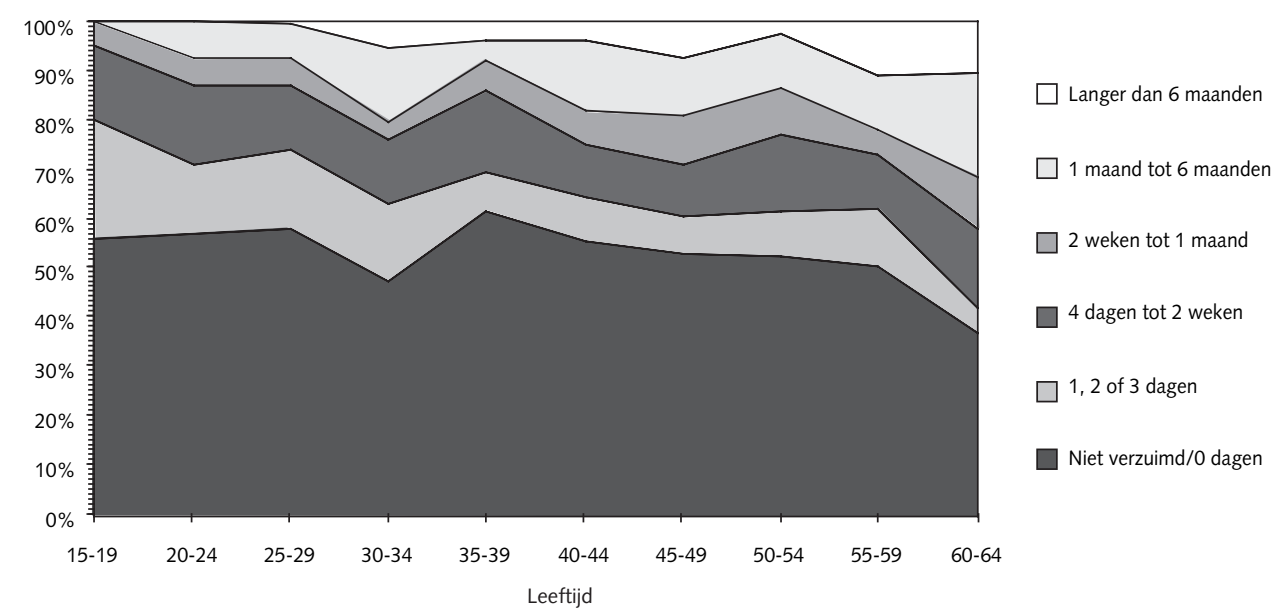

Figuur 2 Verzuim en verzuimduur na een arbeidsongeval naar leeftijd $(N=1.394)$

werk verhogen de kans op een arbeidsongeval dus in sterke mate, de kans op een arbeidsongeval wordt daarmee ongeveer twee keer zo hoog.

Wat betreft de kans op een arbeidsongeval mét verzuim, geldt een vergelijkbaar patroon voor de bedrijfsfactoren. Het eerder gevonden effect van werkdruk, emotioneel zwaar werk en gevaarlijke stoffen is echter niet langer significant. Wat de persoonsvariabelen betreft vinden we dat de kans op een arbeidsongeval mét verzuim 33 procent kleiner is voor vrouwen dan voor mannen $(R R=0,67)$. Ook hoog opgeleiden hebben een relatief kleine kans op een arbeidsongeval mét verzuim $(R R=0,72)$.

Ten slotte kijken we naar de kans op een ongeval met verzuim van een maand of meer. In overeenstemming met figuur 1 is er ook multivariaat een significant maar klein positief effect van leeftijd op ongevallen met verzuim van minimaal één maand $(R R=1,02)$. Tevens is er een significant effect van geslacht $(R R=0,67$, vrouwen hebben minder kans op een ongeval met een maand verzuim of meer). De kans op een ongeval met verzuim van een maand of meer is kleiner naarmate men relatief meer autonomie rapporteert $(R R=0,70)$, groter als er meer sprake is van agressie op het werk $(R R=2,31)$, en ook groter als men gevaarlijk werk doet $(R R=1,98)$. Werknemers met een arbeidshandicap hebben zelfs een bijna drie keer zo grote kans op een arbeidson- geval met verzuim langer dan een maand, in vergelijking met 'gezonde' werknemers $(R R=$ $2,82)$.

In tabel 2 zijn de resultaten van de regressieanalyse voor bedrijfstak opgenomen. De variabele bedrijfstak is afzonderlijk geanalyseerd, dus zonder correctie voor de andere variabelen, omdat veel variabelen geacht worden bijna intrinsiek bij een bedrijfstak te horen. Ook na correctie voor bedrijfstak blijft er een daling in het totale aantal arbeidsongevallen met de leeftijd. Hetzelfde geldt voor de stijging in arbeidsongevallen met langdurig verzuim. Dit betekent dat deze veranderingen niet worden verklaard doordat men systematisch in andere bedrijfstakken gaat werken als men ouder wordt.

In tabel 2 is eveneens te zien dat er grote verschillen zijn tussen de bedrijfstakken wat betreft de kans op een ongeval. In de 'Landbouw en visserij' en in de 'Horeca' is de kans op een ongeval (met en zonder verzuim) ruim driemaal zo groot als in de 'Zakelijke dienstverlening', de referentiegroep. De 'Bouwnijverheid' valt op door een grote kans op ongevallen met verzuim (kort en langer) en de sector 'Cultuur en overige dienstverlening' door een grote kans op ongevallen met een maand verzuim of meer. Met uitzondering van de sector 'Financiële dienstverlening', die een significant lager ongevalrisico heeft, en 'Onderwijs' waarbij geen significant verschil 
Vergrijzing en arbeidsveiligheid

Tabel 1 Regressietabel met de hoofdeffecten van demografische en persoonsfactoren en bedrijfsfactoren op de kans op een arbeidsongeval, een arbeidsongeval met verzuim en een arbeidsongeval met een maand verzuim of meer

\begin{tabular}{|c|c|c|c|c|c|c|}
\hline & \multicolumn{2}{|l|}{ Ongeval } & \multicolumn{2}{|c|}{$\begin{array}{l}\text { Ongeval } \\
\text { met verzuim }\end{array}$} & \multicolumn{2}{|c|}{$\begin{array}{l}\text { Ongeval met } \\
\text { een maand } \\
\text { verzuim of meer }\end{array}$} \\
\hline & $\begin{array}{l}\text { Relatief } \\
\text { Risico }\end{array}$ & $p$ & $\begin{array}{l}\text { Relatief } \\
\text { Risico }\end{array}$ & $p$ & $\begin{array}{l}\text { Relatief } \\
\text { Risico }\end{array}$ & $p$ \\
\hline Leeftijd (per jaar) & 1,00 & 0,24 & 0,99 & 0,32 & 1,02 & 0,03 \\
\hline Geslacht $(1=\operatorname{man}, 2=$ vrouw $)$ & 0,94 & 0,31 & 0,67 & 0,001 & 0,67 & 0,03 \\
\hline Opleiding laag (t/m vbo) & Ref. & & Ref. & & Ref. & \\
\hline Opleiding midden (mbo) & 1,09 & 0,17 & 0,98 & 0,78 & 1,08 & 0,65 \\
\hline Opleiding hoog (hbo/wo) & 0,96 & 0,68 & 0,72 & 0,01 & 0,82 & 0,41 \\
\hline Tijdelijk dienstverband & 0,90 & 0,29 & 0,80 & 0,15 & 0,76 & 0,24 \\
\hline Chronische aandoening & 1,10 & 0,25 & 1,13 & 0,34 & 0,84 & 0,52 \\
\hline Arbeidshandicap & 1,29 & 0,004 & 1,60 & 0,001 & 2,82 & 0,001 \\
\hline Bedrijfsgrootte $\geq 100$ & 0,96 & 0,44 & 0,88 & 0,12 & 0,80 & 0,17 \\
\hline Werkdruk > mediaan & 1,17 & 0,01 & 1,16 & 0,10 & 0,95 & 0,77 \\
\hline Autonomie $>$ mediaan & 0,81 & 0,001 & 0,76 & 0,002 & 0,70 & 0,03 \\
\hline Emotioneel zwaar werk > mediaan & 1,26 & 0,001 & 1,14 & 0,13 & 0,94 & 0,71 \\
\hline Fysieke belasting op het werk $>$ mediaan & 2,16 & 0,001 & 2,02 & 0,001 & 1,24 & 0,31 \\
\hline Geluidslast op het werk > mediaan & 1,27 & 0,001 & 1,41 & 0,001 & 1,28 & 0,17 \\
\hline Agressie op het werk > mediaan & 1,89 & 0,001 & 1,90 & 0,001 & 2,31 & 0,001 \\
\hline Beeldschermwerk $\geq 3$ uur & 0,78 & 0,001 & 0,78 & 0,02 & 0,83 & 0,35 \\
\hline Gevaarlijk werk & 2,31 & 0,001 & 1,94 & 0,001 & 1,98 & 0,001 \\
\hline Gevaarlijke stoffen & 1,19 & 0,008 & 1,05 & 0,61 & 1,09 & 0,66 \\
\hline
\end{tabular}

Noot. De interactietermen tussen leeftijd en elk van de andere factoren zijn voor het overzicht uit de tabel gelaten.

Deze worden in de tekst en de figuren behandeld. Alle factoren worden voor elkaar gecorrigeerd. Weergegeven zijn relatieve risico's. Zo is er als men aangeeft gevaarlijk werk te doen 2,31 keer zoveel kans op een ongeval dan in de referentiecategorie (geen gevaarlijk werk).

Tabel 2 Regressietabel met de hoofdeffecten van bedrijfstak en leeftijd op de kans op een arbeidsongeval, een arbeidsongeval met verzuim en een arbeidsongeval met een maand verzuim of meer

\begin{tabular}{|c|c|c|c|c|c|c|}
\hline & \multicolumn{2}{|l|}{ Ongeval } & \multicolumn{2}{|c|}{$\begin{array}{l}\text { Ongeval } \\
\text { met verzuim }\end{array}$} & \multicolumn{2}{|c|}{$\begin{array}{l}\text { Ongeval met } \\
\text { een maand } \\
\text { verzuim of meer }\end{array}$} \\
\hline & $\begin{array}{l}\text { Relatief } \\
\text { Risico }\end{array}$ & $p$ & $\begin{array}{l}\text { Relatief } \\
\text { Risico }\end{array}$ & $p$ & $\begin{array}{l}\text { Relatief } \\
\text { Risico }\end{array}$ & $p$ \\
\hline Leeftijd (per jaar) & 0,989 & 0,001 & 0,995 & 0,18 & 1,026 & 0,001 \\
\hline Landbouw en visserij & 3,08 & 0,001 & 3,18 & 0,001 & 3,78 & 0,02 \\
\hline Industrie & 2,09 & 0,001 & 2,17 & 0,001 & 2,06 & 0,04 \\
\hline Bouwnijverheid & 2,65 & 0,001 & 3,20 & 0,001 & 4,86 & 0,001 \\
\hline Handel & 1,89 & 0,001 & 2,07 & 0,001 & 1,99 & 0,04 \\
\hline Horeca & 3,62 & 0,001 & 3,31 & 0,001 & 0,93 & 0,94 \\
\hline Vervoer en communicatie & 2,34 & 0,001 & 2,87 & 0,001 & 3,00 & 0,004 \\
\hline Financiële dienstverlening & 0,37 & 0,001 & 0,44 & 0,05 & 1,16 & 0,79 \\
\hline Zakelijke dienstverlening & Ref. & & Ref. & & Ref. & \\
\hline Openbaar bestuur & 1,72 & 0,001 & 1,61 & 0,02 & 1,83 & 0,11 \\
\hline Onderwijs & 1,02 & 0,92 & 0,76 & 0,34 & 0,69 & 0,55 \\
\hline Gezondheids- en welzijnszorg & 2,33 & 0,001 & 1,35 & 0,11 & 1,47 & 0,28 \\
\hline Cultuur en overige dienstverlening & 1,86 & 0,001 & 2,05 & 0,004 & 3,64 & 0,001 \\
\hline
\end{tabular}

Noot. De interactietermen tussen leeftijd en elk van de bedrijfstak-dummyvariabelen zijn voor het overzicht uit de tabel gelaten. Deze worden in de tekst en de figuren behandeld. De variabele bedrijfstak is afzonderlijk geanalyseerd.

Weergegeven zijn relatieve risico's. Zo is er in de horeca 3,62 keer zoveel kans op een ongeval dan in de referentiecategorie (zakelijke dienstverlening). 
met de 'Zakelijke dienstverlening' werd gevonden, is in alle andere bedrijfstakken de relatieve kans op een arbeidsongeval groter dan in de 'Zakelijke dienstverlening'.

Uit de gevonden interactie-effecten blijkt dat er subgroepen zijn waarvoor het effect van leeftijd op het ongevalrisico anders uitvalt. Vooral interacties die aantonen dat bij oudere werknemers een ander effect van een of meer van de factoren wordt gevonden dan in de totale groep, zijn gezien de vraagstelling interessant. Voor de kans op een arbeidsongeval is dit het geval voor de aard van het dienstverband en voor de mate van autonomie. Voor de kans op een arbeidsongeval mét verzuim geldt dit voor dezelfde variabelen, en ook voor de mate van agressie op het werk. In de categorie arbeidsongevallen met verzuim van een maand of langer werden geen significante interactie-effecten gevonden.

In figuur 3 is te zien dat de eerder geconstateerde daling van de kans op een ongeval met leeftijd, zich hoofdzakelijk voordoet in de subgroep respondenten die relatief veel autonomie in hun werkzaamheden ervaren. Dit is verklaarbaar als we bedenken dat ouderen meer 'safety conscious' zijn. Meer autonomie zal ouderen mogelijk meer 'kansen' bieden hun 'safety consciousness' in praktijk te bren- gen en mogelijk op die manier leiden tot veiliger gedrag. Bij werknemers met een lage autonomie lijkt de kans op een ongeval zelfs iets te stijgen naarmate de werknemer ouder is.

Het interactie-effect tussen leeftijd en de aard van het dienstverband op het hebben gehad van een ongeval (al dan niet met verzuim) duidt erop dat de daling van de kans op een ongeval met de leeftijd zich vooral voordoet in de groep werknemers met een tijdelijke aanstelling. Nadere analyse lijkt er echter op te wijzen dat tijdelijke aanstellingen zowel vaker bij jongeren voorkomen als relatief vaak in de horecasector. De horeca is 'recordhouder' tijdelijke aanstellingen: 42,2 procent van de respondenten die in de horeca werken heeft een tijdelijke aanstelling, terwijl dat gemiddeld over de gehele groep 'slechts' 16,6 procent is. Respondenten met een tijdelijke aanstelling zijn gemiddeld 30 jaar oud, en met een vaste aanstelling is de gemiddelde leeftijd 41 jaar. De horeca is eveneens koploper in het aantal arbeidsongevallen $(12,4 \%$ van de respondenten in die sector had de laatste twaalf maanden een arbeidsongeval, tegen 'slechts' $6,6 \%$ in de gehele groep). Doordat jongeren relatief veel in tijdelijke aanstellingen en in de horeca werken waar zich relatief veel ongevallen voordoen, ontstaat er een associatie tussen tijdelijke aanstellingen en ongevallen.

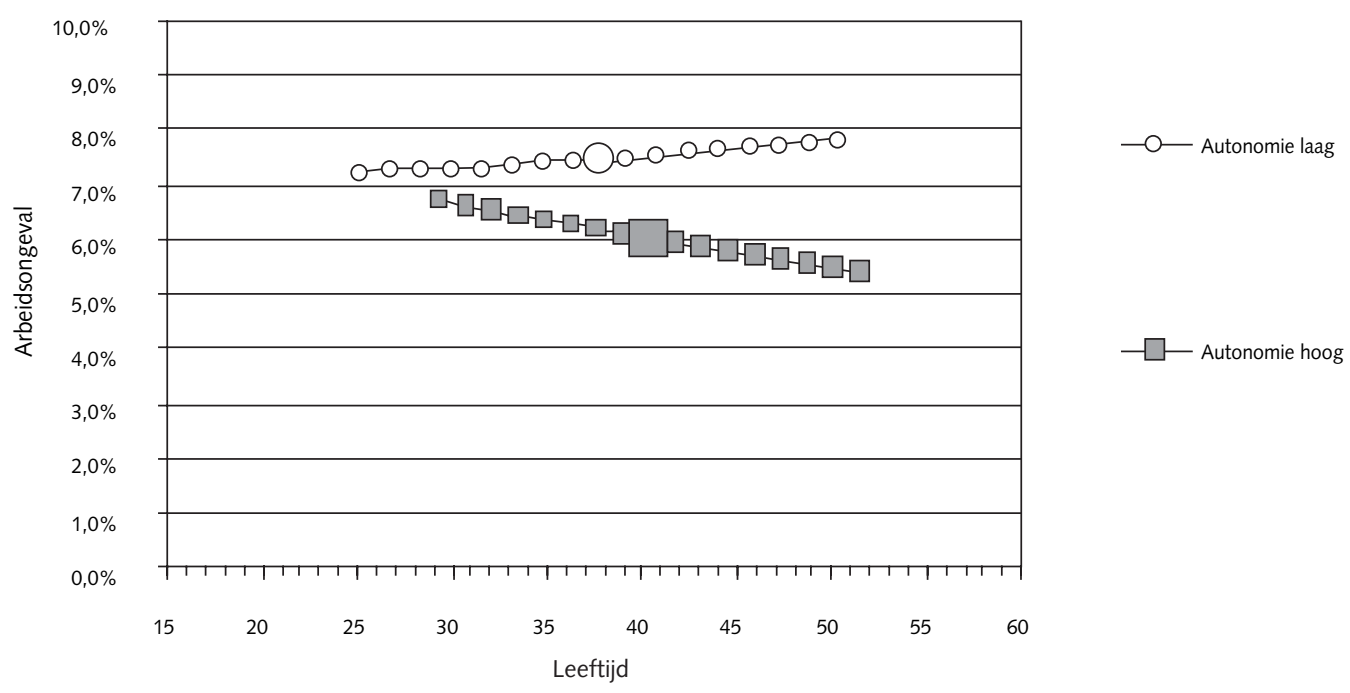

Figuur 3 Kans op een arbeidsongeval naar leeftijd en ervaren autonomie $(N=20.986)$ 
Vergrijzing en arbeidsveiligheid

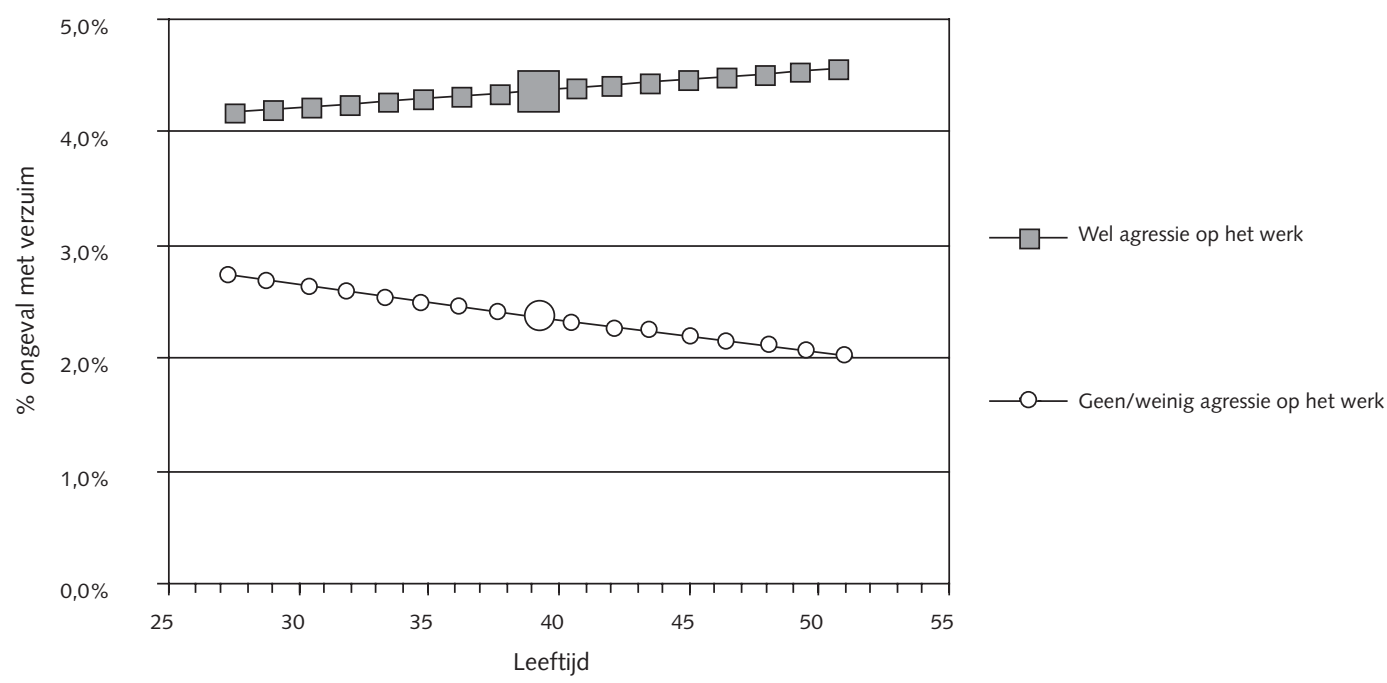

Figuur 4 Kans op een arbeidsongeval mét verzuim naar leeftijd en ervaren agressie $(N=20.986)$

In figuur 1 zagen we dat de kans op een arbeidsongeval mét verzuim daalt naarmate de respondenten ouder zijn. Figuur 4 laat zien dat dit effect zich hoofdzakelijk voordoet in de subgroep die relatief weinig agressie op het werk ervaart. Oudere werknemers die tevens een hoge mate van agressie op het werk ervaren, vormen dus een risicogroep voor arbeidsongevallen met verzuim.
Figuur 5 laat zien dat de duidelijke daling van de kans op een arbeidsongeval (al dan niet met verzuim/ zich niet lijkt voor te doen in de sectoren 'Horeca', 'Vervoer en communicatie', 'Handel' en 'Onderwijs'. De figuur beperkt zich tot deze vier sectoren, aangevuld met de referentiesector 'Zakelijke dienstverlening'. In deze figuur is in tegenstelling tot de andere figuren niet gecorrigeerd voor de andere varia-

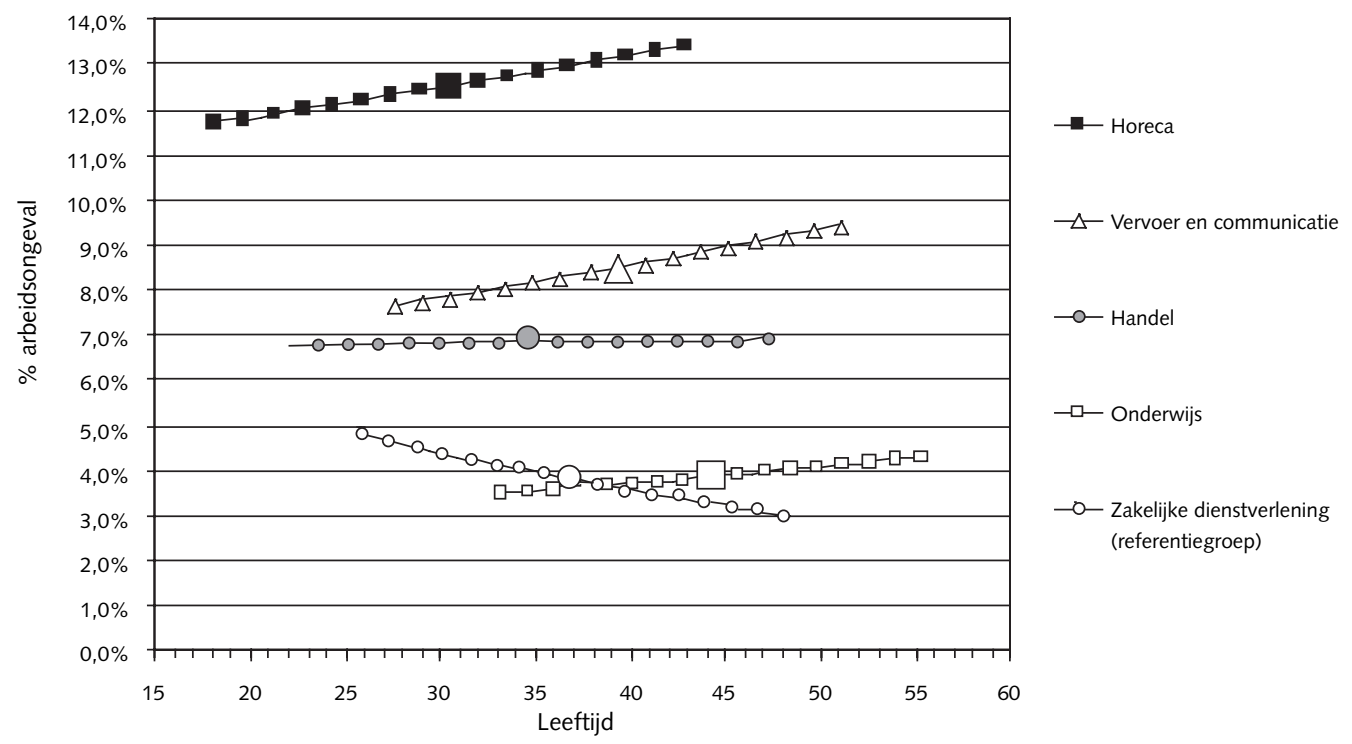

Figuur 5 Kans op een arbeidsongeval naar leeftijd en bedrijfstak $(N=20.986)$ 
belen. In het geval van de 'Horeca' kan de relatieve stijging mogelijk samenhangen met systematische veranderingen in het soort werk dat jongeren en ouderen in de horeca verrichten. Mogelijk verrichten oudere werknemers in de horeca gevaarlijker werk dan jongeren (bijvoorbeeld meer in de keuken dan in de bediening). Bij 'Vervoer en communicatie' spelen mogelijk een met de leeftijd samenhangend verminderd reactievermogen en een verminderd gezichtsvermogen een rol.

\section{Conclusies}

De vergrijzing schrijdt voort en dit is merkbaar op de arbeidsmarkt. Het aandeel oudere werknemers stijgt. Leeftijdsbewust personeelsbeleid wordt steeds belangrijker. Geldt dit ook voor veiligheid? In dit artikel is een aantal onderzoeksvragen gesteld, die licht werpen op deze kwestie.

\section{Wat is de samenhang tussen leeftijd en het ongevallenpercentage in 2005 ?}

Uit de secundaire analyse op de Nationale Enquête Arbeidsomstandigheden kunnen we afleiden dat leeftijd een rol speelt bij de kans op een arbeidsongeval. In het algemeen kan worden gesteld dat jongeren het hoogste risico lopen op een arbeidsongeval, en dat een toename van het aantal oudere werknemers op de arbeidsmarkt een gunstig effect kan hebben op het totale aantal arbeidsongevallen in Nederland. De kans op een arbeidsongeval wordt immers lager naarmate de leeftijd van de werkende stijgt. Uit de multivariate analyse blijkt echter dat het positieve effect van leeftijd op arbeidsongevallen en op verzuimen na een ongeval volledig wordt verklaard door andere persoons- en werkkenmerken.

\section{Neemt de duur van het verzuim toe naarmate de betrokken werknemer ouder is?}

Daarnaast is gekeken naar de duur van het verzuim als gevolg van een arbeidsongeval naar leeftijd. De verwachting hierbij was dat oudere werknemers een hoger risico hebben dan jongere werknemers op ongevallen met langdurig verzuim, aangezien ouderen mogelijk een hoger risico lopen op ernstig letsel en daarvan langer moeten herstellen. We concluderen dat in de subgroep die een ongeval heeft gehad, de verzuimduur 'als gevolg van dat ongeval' enigszins toeneemt met de leeftijd. De hypothese dat ouderen meer hersteltijd nodig hebben wordt bevestigd, al moet daarbij de kanttekening worden gemaakt dat de gevonden samenhang niet zeer sterk is. Tevens concluderen we dat de kans op een arbeidsongeval met verzuim van een maand of meer enigszins stijgt met de leeftijd. Dit beperkt het positieve effect van de vergrijzing op arbeidsongevallen, aangezien dat niet geldt voor de arbeidsongevallen met langdurig verzuim die wel de meeste kosten meebrengen voor de werkgever.

\section{In welke subgroepen is de relatie tussen leeftijd en arbeidsongevallen vooral sterk negatief of juist positief?}

Nagegaan is of er subgroepen zijn aan te wijzen waarbij de relatie tussen ongevalrisico en leeftijd zich anders 'gedraagt', waardoor er aanleiding is voor deze groepen een ander beleid te voeren. We kunnen ten aanzien van de volgende factoren een voorbehoud maken bij de verwachte positieve effecten van de vergrijzing op de kans op arbeidsongevallen. Ten eerste is de leeftijdsgebonden daling van de kans op een arbeidsongeval vooral van toepassing op werknemers die relatief veel autonomie in hun werk ervaren. Er lijkt zelfs een lichte leeftijdsgebonden stijging te zijn van de kans op een arbeidsongeval bij werknemers met een lage mate van autonomie. Ten aanzien van agressie kan worden geconcludeerd dat met name ouderen die én relatief veel agressie in hun werk ervaren én een arbeidsongeval krijgen, het meeste risico lopen ten gevolge van dat ongeval te verzuimen. Wellicht is de weerbaarheid onder oudere werknemers ten aanzien van de combinatie van deze twee risicofactoren van verzuim relatief kleiner dan onder jongere werknemers. Ten slotte vonden we dat in bepaalde bedrijfstakken de kans op een arbeidsongeval enigszins toeneemt met de leeftijd. Het betreft vooral de bedrijfstakken 'Horeca' en 'Vervoer en communicatie', met name in deze bedrijfstakken kan de toenemende vergrijzing leiden tot een toename van het aantal arbeidsongevallen.

De in dit artikel gerapporteerde analyses zijn uitgevoerd op een bestaand, cross-sectioneel databestand. Daardoor is het niet mogelijk een- 
duidige oorzakelijke verbanden aan te wijzen en is er minder informatie aanwezig dan voor dit onderwerp wenselijk was geweest. Er is bijvoorbeeld geen informatie beschikbaar over andere ongevalgevolgen dan het optreden van verzuim en de verzuimduur. Bij het wel of niet verzuimen na een arbeidsongeval speelt een groot aantal factoren mee, zoals de verzuimbereidheid. In de inleiding is al aangegeven dat ouderen zich minder vaak ziek melden na een arbeidsongeval. Smulders (2005) vond dat de algemene verzuimfrequentie lager is bij ouderen dan bij jongeren, maar dat het totale aantal dagen verzuim per jaar substantieel toeneemt. Dit betekent dat de afhankelijke variabelen arbeidsongeval met verzuim en arbeidsongeval met verzuim van een maand of meer, mogelijk door verschillende factoren worden beïnvloed. We hebben voor alle drie de afhankelijke variabelen echter een duidelijk overeenkomstig patroon van effecten gevonden. Hieruit concluderen we dat bijvoorbeeld de verzuimbereidheid in dit onderzoek geen groot verstorend effect zal hebben gehad op de resultaten.

Concluderend kunnen we dus verwachten dat de toename van het aantal oudere werkenden in de nabije toekomst tot een daling van het aantal arbeidsongevallen in Nederland zal leiden, omdat voor ouderen in het algemeen het ongevalrisico lager is dan voor jongere werkenden. Hierbij is echter een aantal kanttekeningen te plaatsen. Specifieke aandacht voor arbeidsongevallen in het leeftijdsbewust personeelsbeleid is vooral zinvol voor bedrijven met relatief weinig autonomie voor de werknemers, bedrijven waar relatief vaker sprake is van agressie op de werkplek, en bedrijven in de sectoren 'Horeca' en 'Vervoer en communicatie'. Het aantal ongevallen met ernstige gevolgen in termen van verzuimduur zal door de toenemende vergrijzing bovendien niet afnemen. Omdat het voor werkgevers relatief dure ongevallen betreft, verdient het aanbeveling om met name onder ouderen aandacht te besteden aan verzuim en re-integratiebegeleiding na een arbeidsongeval. onderzoek op het beleidsterrein van het ministerie van SZW.

\section{Literatuur}

Boer, A. de (red.) (2006). Rapportage ouderen 2006: Veranderingen in de leefsituatie en levensloop. Den Haag: Sociaal en Cultureel Planbureau.

Bossche, S.N.J. van den, S.L.H. Hupkens, S.J.M. Ree \& P.G.W. Smulders (2006). Nationale Enquête Arbeidsomstandigheden 2005: Methodologie en globale resultaten. Hoofddorp: TNO Kwaliteit van Leven.

CBS Webmagazine (2006). Kwart werkzame bevolking is 50-plus. CBS Webmagazine, 8 mei 2006.

CPB (2005). Centraal Economisch Plan. Den Haag: Centraal en Cultureel Planbureau.

Frone, M.R. (1998). Predictors of work injuries among employed adolescents. Journal of Applied Psychology, 83: 565-576.

Frone, M.R. \& J. Barling (2004). Common themes and future directions. In: J. Barling \& M.R. Frone (eds). The psychology of workplace safety (pp.299-307). Washington: American Psychological Association (APA).

Loughlin, C. \& M.R. Frone (2004). Young workers' occupational safety. In: J. Barling \& M.R. Frone (eds). The psychology of workplace safety (pp.107-127). Washington: American Psychological Association (APA).

Pransky, G.S., K.L. Benjamin, J.A. Savageau, D. Currivan \& K. Fletcher (2005). Outcomes in work-related injuries: A comparison of older and younger workers. American Journal of Industrial Medicine, 47: 104-112.

Rogers, E. \& W.J. Wiatrowski (2005). Injuries, illnesses, and fatalities among older workers. Monthly Labor Review, October, pp. 24-30.

SER (2006). Wegnemen belemmeringen voor doorwerken na 65 jaar. Advies nr. 06/03. Den Haag: Sociaal-Economische Raad.

Skov, T., J. Deddens, M.R. Petersen \& L. Endahl (1998). Prevalence proportion ratios: Estimation and hypothesis testing. International Journal of Epidemiology, 27: 91-93.

Smulders, P.G.W. (2005). Jongere en oudere werknemers: Hun werk, werktijden, ongevallen en verzuim. Hoofddorp: TNO kwaliteit van Leven.

Thompson, M.L., J.E. Myers \& D. Kriebel (1998). Prevalence odds ratio or prevalence ratio in the analysis of cross-sectional data: What is to be done? Occupational and Environmental Medicine, 55: 272-277.

Venema, A. \& A. Bloemhoff (red.) (2006). Monitor Arbeidsongevallen in Nederland, 2004. Hoofddorp: TNO Kwaliteit van Leven.

\section{Noot}

1 Deze publicatie is tot stand gekomen met behulp van door de overheid aan TNO beschikbaar gestelde financiële middelen ten behoeve van 